\title{
Guillain-Barré syndrome after tetanus toxoid, reduced diphtheria toxoid and acellular pertussis vaccine: a case report
}

\author{
Hussam Ammar
}

\begin{abstract}
Introduction: The association of Guillain-Barré syndrome with vaccination has been described in the literature; it is infrequent and controversial. An association with swine influenza, influenza, hepatitis and tetanus vaccination has been documented in few case reports.

Case presentation: A 40-year-old Caucasian man sustained a small right temporal epidural hematoma and nondisplaced right skull fractures after a fall from a roof. He was managed conservatively; a tetanus toxoid, reduced diphtheria toxoid and acellular pertussis vaccine was administered and a week later he was discharged home. A few days after his discharge, he experienced weakness and numbness in his legs, which progressed to involve his arms. Three weeks after his initial fall, he was readmitted with quadriparesis. A lumbar puncture revealed a cerebrospinal fluid protein of $790 \mathrm{mg} / \mathrm{dL}$ and one white blood cell. We diagnosed Guillain-Barré syndrome. Our patient was treated with intravenous immunoglobulin. Three months later his muscle strength had improved, but he continued to have tingling in his hands and feet and used a walker intermittently.

Conclusion: To the best of our knowledge, this is the first case of Guillain-Barré syndrome to be reported in the English literature after administration of tetanus toxoid, reduced diphtheria toxoid and acellular pertussis vaccine.
\end{abstract}

\section{Introduction}

The association of Guillain-Barré syndrome (GBS) with vaccination has been described but is infrequent and, in many settings, is controversial. A small but statistically significant elevated risk of GBS was noted among swine flu vaccinees relative to non vaccinees in 1976 [1].

The influenza vaccine in the 1992 to 1994 vaccine campaign was associated with a very small increased risk, of one GBS case per million vaccinees. Hepatitis vaccinations were also suggested to be associated with GBS [1]. The association of tetanus vaccination and GBS is documented in only a few case reports (1-5).

\section{Case presentation}

A 40-year-old Caucasian man fell from a second story roof. He sustained a small right temporal epidural hematoma, a nondisplaced right temporal scalp fracture

Correspondence: hussam.m.ammar@uth.tmc.edu

Internal Medicine Department, University at Texas, Health Science Center at Houston, Fannin, Houston, TX 77030, USA and a zygomatic arch fracture. His neurological examination was normal.

A tetanus toxoid, reduced diphtheria toxoid and acellular pertussis vaccine (Tdap; Boostrix) was administered. He was managed conservatively and discharged home one week later.

A few days after his discharge, our patient experienced weakness and numbness in his legs, which progressed to involve his arms. Three weeks after his initial fall, he was readmitted to our hospital with severe weakness. His muscle strength was $2 / 5$ in his lower extremities and $3 / 5$ in his upper extremities. His deep tendon reflexes were absent at his ankles and knees and were diminished in his upper extremities. There was bilateral peripheral facial paresis, bulbar weakness and impaired gag reflex. He had diminished touch and pin prick sensation in a stocking glove distribution.

His vital capacity was reduced to 1.4 liters. Magnetic resonance imaging of his brain and spinal cord were unremarkable. A lumbar puncture revealed a 
Table 1 Cases describing the association of tetanus vaccination and GBS

\begin{tabular}{|c|c|c|c|c|c|}
\hline Case & $\begin{array}{l}\text { Tetanus } \\
\text { containing } \\
\text { vaccine }\end{array}$ & $\begin{array}{l}\text { Onset of } \\
\text { symptoms } \\
\text { after } \\
\text { vaccination }\end{array}$ & Clinical presentation & Treatment & Outcome \\
\hline \multirow[t]{3}{*}{ [3] } & $\begin{array}{l}\text { Tetanus toxoid } \\
(1962,1971,1976)\end{array}$ & $\begin{array}{l}\text { First episode: } \\
\text { three weeks }\end{array}$ & $\begin{array}{l}\text { First episode: Progressive limb weakness. CSF was } \\
\text { normal except a protein level of } 300 \mathrm{mg} / \mathrm{dL} \text {. }\end{array}$ & $\begin{array}{l}\text { Symptomatic } \\
\text { treatment and } \\
\text { physical therapy. }\end{array}$ & $\begin{array}{l}\text { First episode: Complete recovery } \\
\text { after two months. }\end{array}$ \\
\hline & & $\begin{array}{l}\text { Second } \\
\text { episode: two } \\
\text { weeks }\end{array}$ & $\begin{array}{l}\text { Second episode: Tingling and numbness, mild } \\
\text { weakness, loss of position sense, absent DTR. CSF } \\
\text { was normal except a protein level of } 250 \mathrm{mg} / \mathrm{dL} \text {. }\end{array}$ & & $\begin{array}{l}\text { Second episode: Recovery after } \\
\text { eight months with slight hand } \\
\text { tremors. }\end{array}$ \\
\hline & & $\begin{array}{l}\text { Third episode: } \\
10 \text { days }\end{array}$ & $\begin{array}{l}\text { Third episode: Tingling and numbness, unable to } \\
\text { walk, loss of position sense and diminished pin prick } \\
\text { sensation below knees. }\end{array}$ & & $\begin{array}{l}\text { Third episode: Patient had only } \\
\text { mild hand weakness by day } 12 \text {. }\end{array}$ \\
\hline [4] & Tetanus toxoid. & Nine days & $\begin{array}{l}\text { Tingling and numbness, profound weakness of the } \\
\text { extremities, bilateral peripheral facial paresis, bulbar } \\
\text { weakness, bilateral weakness of ocular abduction. } \\
\text { DTR were absent. Touch and pin prick sensation } \\
\text { were diminished distally in lower extremities. Vital } \\
\text { capacity was } 1.6 \mathrm{~L} \text {. CSF protein level was } 550 \mathrm{mg} / \mathrm{dL} \text {, } \\
\text { no pleocytosis. }\end{array}$ & $\begin{array}{l}\text { Symptomatic } \\
\text { treatment and } \\
\text { physical therapy }\end{array}$ & $\begin{array}{l}\text { Discharge after } 57 \text { days with } \\
\text { mild left leg weakness. }\end{array}$ \\
\hline [5] & Tetanus toxoid. & Four days & $\begin{array}{l}\text { Tingling of finger tips and toes, moderate weakness } \\
\text { of four extremities. DTR were absent at ankles, knees } \\
\text { and triceps. There was bilateral facial weakness and } \\
\text { dysphagia. Position and vibration sense was } \\
\text { diminished distally in four extremities. CSF protein } \\
\text { level was } 70 \mathrm{mg} / \mathrm{dL} \text {. }\end{array}$ & $\begin{array}{l}\text { Intravenous } \\
\text { immunoglobulin } \\
\text { and physical } \\
\text { therapy }\end{array}$ & $\begin{array}{l}\text { Significant improvement at six } \\
\text { weeks. Residual facial weakness } \\
\text { and painful twitching in both } \\
\text { arms. }\end{array}$ \\
\hline
\end{tabular}

cerebrospinal fluid protein of $790 \mathrm{mg} / \mathrm{dL}$ and one white blood cell.

We diagnosed GBS. Nerve conduction studies revealed prolongation of the upper and lower motor action potential latencies, reduced motor conduction velocities and reduced amplitude. Median and ulnar nerves sensory action potentials were absent. Our patient was treated with intravenous immunoglobulin and his muscle strength improved. Three months later he continued to have tingling in his hands and feet and use a walker intermittently.

\section{Discussion}

The association of tetanus toxoid containing vaccines and GBS is documented in a small number of case reports, outlined in Table 1[1-5].

The Advisory Committee on Immunization Practice considers development of GBS less than six weeks after receiving a tetanus toxoid-containing vaccine a precaution for subsequent tetanus toxoid-containing vaccinations.

The Institute of Medicine favored the acceptance of causal relationship between tetanus toxoid-containing vaccine and GBS based on a single documented case report [2]. A subsequent analysis estimated the number of cases of GBS observed after a tetanus toxoid-containing vaccine to be less than the number caused by chance alone $[1,2]$.
Our patient didn't have diarrhea, fever, cough or chills in the weeks preceding his illness. The only recognized event was receiving the Tdap vaccine one week before his illness.

\section{Conclusion}

To the best of our knowledge, this is the first case of GBS to be reported in the English literature after administration of a Tdap vaccine.

\section{Consent}

Written informed consent was obtained from the patient for publication of this case report and any accompanying images. A copy of the written consent is available for review by the Editor-in-Chief of this journal.

\section{Competing interests}

The author declares that they have no competing interests.

Received: 17 June 2011 Accepted: 5 October 2011

Published: 5 October 2011

\section{References}

1. Van Doorn PA, Ruts L, Jacobs BC: Clinical features, pathogenesis, and treatment of Guillain-Barré syndrome. Lancet Neurol 2008, 7(10):939-950.

2. Kretsinger K, Broder KR, Cortese MM, Joyce MP, Ortega-Sanchez I, Lee GM, Tiwari T, Cohn AC, Slade BA, Iskander JK, Mijalski CM, Brown KH, Murphy TV, Centers for Disease Control and Prevention; Advisory Committee on Immunization Practices; Healthcare Infection Control Practices Advisory Committee: Preventing tetanus, diphtheria, and pertussis among adults: use of tetanus toxoid, reduced diphtheria toxoid and acellular pertussis 
vaccine recommendations of the Advisory Committee on Immunization Practices (ACIP) and recommendation of ACIP, supported by the Healthcare Infection Control Practices Advisory Committee (HICPAC), for use of Tdap among health-care personnel. MMWR Recomm Rep 2006, 55(RR-17):1-37.

3. Pollard JD, Selby G: Relapsing neuropathy due to tetanus toxoid. Report of a case. J Neurol Sci 1978, 37(1-2):113-125.

4. Newton N Jr, Janati AP: Guillain-Barré syndrome after vaccination with purified tetanus toxoid. South Med J 1987, 80(8):1053-1054.

5. Bakshi R, Graves MC: Guillain-Barré syndrome after combined tetanusdiphtheria toxoid vaccination. J Neurol Sci 1997, 147(2):201-202.

doi:10.1186/1752-1947-5-502

Cite this article as: Ammar: Guillain-Barré syndrome after tetanus

toxoid, reduced diphtheria toxoid and acellular pertussis vaccine: a case report. Journal of Medical Case Reports 2011 5:502.

\section{Submit your next manuscript to BioMed Central} and take full advantage of:

- Convenient online submission

- Thorough peer review

- No space constraints or color figure charges

- Immediate publication on acceptance

- Inclusion in PubMed, CAS, Scopus and Google Scholar

- Research which is freely available for redistribution

Submit your manuscript at www.biomedcentral.com/submit 